\title{
ОРГАН-ВЪРХУ-ЧИП, ИЛИ ПЪРВАТА СТЪПКА КЪМ СЪЗДАВАНЕТО НА БИОАРТИФИЦИАЛЕН ОРГАН
}

\author{
Александър Петров, Светла Стайкова, Росица Зорчева-Вътева \\ Втора катедра по вътрешни болести, \\ УС по нефрология, диализа и токсикология, УМБАЛ „Св. Марина“ - Варна
}

\begin{abstract}
PEЗЮME
ЗД принтирането е динамично развиваща се технология, чийто огромен потенциал за приложение придобива бързо развитие и в областта на биомедицинските и инженерни науки. Докато все още невъзможността от принтиране на пълноценна кръвоносна система е един от лимитиращите фактори за създаването на цялостен, паренхимен орган, то от началото на 90-те години една млада научна дисциплина предлага алтернативен път до тази цел. Микрохидродинамиката (от англ. Microfluidics, „Микрофрлуидика“) се занимава с манипулиране поведението на течностите на молекулярно равнище. Приложението е, че например лабораторни методи като ELISA, PCR, както и геномното секвениране, изискващи обемна апаратура и консумативи, биха могли да бъдат пренесени върху чипове с големината на човешки нокът, като запазват информативната си стойност. Друг интересен аспект е така нареченият „орган-върху-чип“. Устройството представлява микродрлуидича клетъчна култура, която за разлика от конвенционалните клетъчни култури може почти напълно да пресъздаде физиологията на органно ниво. Към момента успешно са създадени функииониращи модели на: „черво-върху-чип“, „бял дроб-върху-чип“, „,кръвоносен съд-върху-чип“, „,тумор-върху-чип“, „костен мозък-върху-чип“ и „бъбрек-върху-чип“. „Бъбрекът-върху-чип“се е оказал значително информативен в експериментални условия. Jang KJ et al е наблюдавал пряко нефротоксичния ефект на иисплатина върху проксимални тубулни клетки. Клетъчната увреда е била мониторирана в продължение на 24 часа, с регистриране на биомаркери. В последващия период от 72 часа след премахването на увреждащия агент е регистрирано възстановяване на увредените клетки чрез активиране на аквапорин-2 рецепторите и самостоятелно движение на цитоскелета на тубулните клетки - самият процес е слабо изучен в експериментални модели животни. Друго приложение се намира във фрармацевтичната индустрия, което неимоверно ще ускори разработването на нови лекарствени продукти без странични реакции. Микрохидродинамиката, в съчетание с ЗД принтирането, ще предостави редица възможности за развитие в медицината.
\end{abstract}

Създаването на един нов лекарствен препарат е процес, който е труден, времеемък и изключително скъп. Обобщено може да бъде предствен чрез следните цифри: средна продължителност за достигане до пазара: 15 години, цена на целия процес: около 1 милиард долара. Едва около $12 \%$ от кандидат-лекарствените препарати успяват да преминат през клиничните изпитания и да достигнат до пазара поради неустановени в предклиничната фаза фармакокинетични и фармакодинамични особености и токсичност (1). Конвенционалните предклинични методи имат недостатъци и могат да бъдат разделени в три големи категории: клетъчни култури, животински модели и еx vivo системи. Клетъчните култури са труд- ни за поддръжка, изискват специални лабораторни условия и среда, а жизнената им продължителност рядко надвишава две седмици. Тъй като са с индивидуалните особености на съответния донор, резултатите, получени от провежданите с тях експерименти, често могат да бъдат погрешно екстраполирани и за останалата популация. In vivo животинските модели позволяват изследвания в работеща физиологична среда, но въпреки това междувидовите различия често могат да „укрият“ съществени недостатъци на проучваните лекарствени молекули. От своя страна ех vivo системите представляват експлантирани човешки органи и тъкани, които са най-информативните модели за експерименти, но основният им 
минус е изключително кратката им продължителност на живот: няколко часа след подготовката им. Тези сериозни проблеми налагат необходимостта от нови стратегии.

През последните години се регистрира изключителен напредък в развитието на биоинженерните и компютърни науки, което дава шанс за създаването на нови технологии, които да предоставят решение на тези до момента „непреодолими“ пречки. С появата си (в края на 80-те) една млада наука, наречена „микрофлуидика“ (от анг. microfluidics), бързо се превърна в силен инструмент с редица приложения в научните среди (2). Микрофлуидиката се занимава с поведението, точния контрол и манипулирането на течностите на субмилилитрово ниво, или по-точно в диапазона $10^{-9}$ до $10^{-18}$ I. В периода 1990-2000 година микрофлуидиката се е фокусирала върху разработването на „миниатюризирани химико-аналитични системи (Manz et al.: „,miniaturized total chemical analysis systems" [ $\mu \mathrm{TAS}])$ за химическата индустрия. Но от началото на 2000 г. е възприета нова концепция за провеждане и на експерименти на микрониво в медицината: т.нар. „лаборатории-върху-чип“. Тази концепция бързо е довела до нови приложения, като една от най-значимите идеи е „орган-върху-чип“. „Орган-върху-чип" е биологично устройство, което е населено от живи клетъчни популации, които за разлика от обикновените клетъчни култури в „петрита“, получават адекватна перфузия с непрекъснат ламинарен поток. По този начин не се прави опит за съз- даване на идеално копие на човешки орган, а по-скоро пресъздаване на най-малката му функционална единица - „микрофизиологична система" - Фиг. 1 (от англ. microphysiologic systems [MPSs]) (3).

Става възможно изследването на човешката физиология, реактивността към стрес и имитиране на патофизиологични процеси in vivo. Пряка полза ще има фармацевтичното производство, което ще бъде значително съкратено по времетраене и финансова тежест, защото провеждането на тестове ще бъде директно върху „човешки“ обекти.

За постигането на пълна функционалност на тези устройства са важни редица условия, някои от които са налягането на перфузионния ток, $\mathrm{pH}$, осмотичното налягане, хранителните вещества, очистването на токсините. Първият описан такъв модел е от Huh et al. в Института Wyss във Вашингтон от 2010г. и е „бял дробвърху-чип“ (4). Представлява система, съдържаща два близко разположени микроканала, разделени от тънка $(10 \mu \mathrm{m})$, пореста и гъвкава мембрана от полидиметилсилоксан (PDMS). Създаденият чип позволява изучаването на възпалителни процеси и отговор спрямо бактериални антигени. Това откритие бързо дава тласък за фабрикуването на още подобни микрофизиологични системи. Представители на вече съществуващи модели „орган-върху-чип“ са: „черво-върху-чип“, „кръвоносен съд-върху-чип“, „кожа-върху-чип“, „мозък-върху-чип“, „рак-върху-чип“, „костен мозък-върху-чип“ и разбира се „бъбрек-върху-чип“.

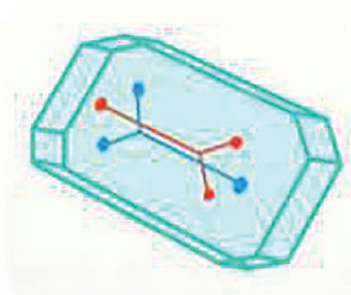

Microfluid design

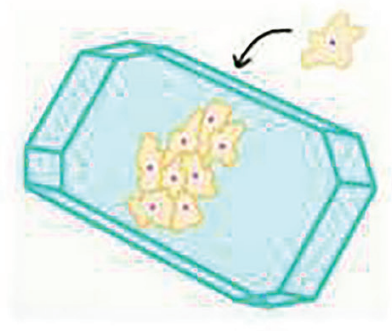

Inoculation

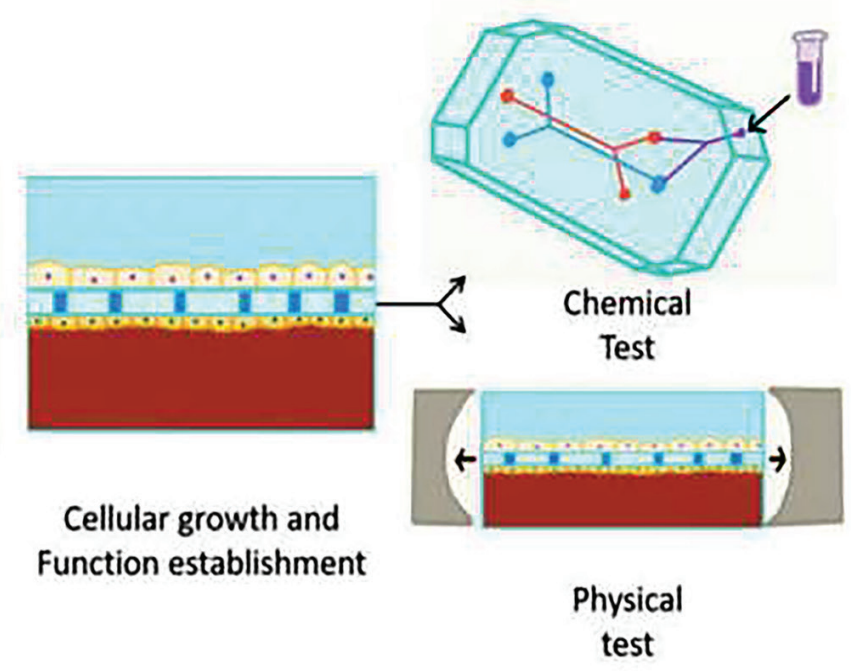

Фиг. 1 
Бъбрекът е един от най-сложно устроените органи в тялото, което прави пресъздаването му „върху-чип“ изключително предизвикателно. Той се състои от гломерул, проксимален тубул, бримка на Хенле (низходяща и възходяща част), дистален тубул, събирателно каналче, мезангиални и ендотелни клетки. Към момента главният фокус е към създаването на физиологичен модел на проксимален тубул - главното място за лекарствения клирънс и първична локализация за лекарствена токсичност. Първоначалният дизайн е имал две съставни части - микрокухини. Горната имитира уринарния лумен и през нея преминава течност, докато долната е интерстициал- ното пространство. Тази структура е била използвана за демонстриране на нефротоксичните ефекти на цисплатината върху тубулния епител (5). През 2013 г. Jang et al. упява да пресъздаде „бъбрек-върху-чип“ с помощта на човешки проксимални тубулни епителни клетки (hPTEC). Сравнен със стандартните клетъчни култури, микрофизиологичният модел е имал по-висок брой на цили, натриево-калиеви АТР-фазни помпи и аквапорин 1 рецептори, както и по-добра резорбционна способност за албумин и глюкоза. Едно от най-новите открития е успешният опит да се пресъздаде гломерулнофилтрационна бариера. Използвани са били индуцирани човешки плурипотент-

\section{Human-on-a-Chip}

\section{Electrochemical biosensors}

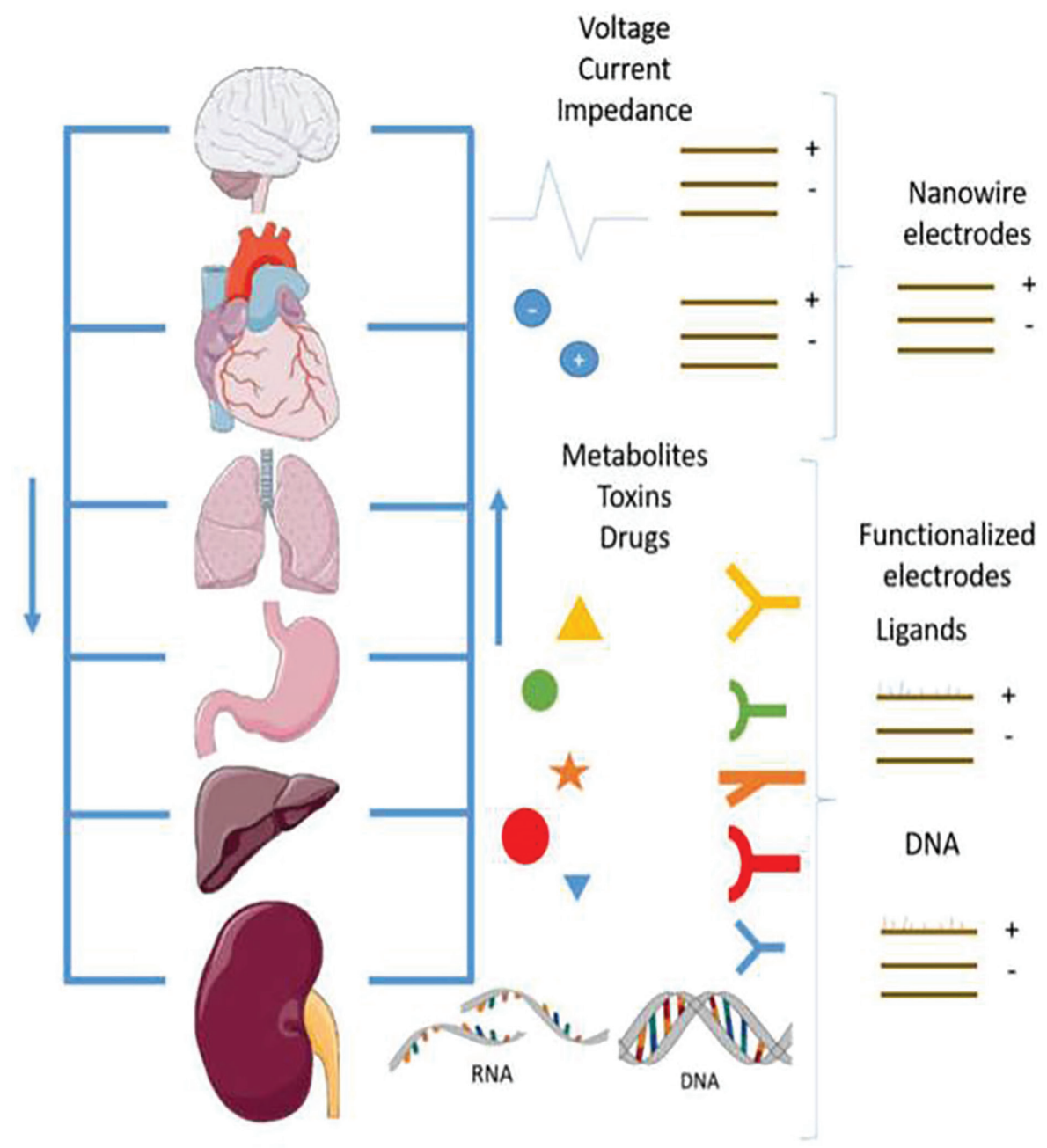

Фиг. 2. Биомедицинските и фармацевтични индустрии биха имали огромна полза от подобни успешни проекти, касаещи изработването и тестуването на нови лекарствени препарати, което ще направи и експериментите с животни на практика ненужни. Една крачка още по-напред в бъдещето би била създаването на индивидуални "органи-върху-чип", които ще носят характеристиките на биометрични „клетъчни паспорти“. По този начин при наличието на заболяване всеки би могъл предварително да бъде оценен като „подходящ“" или „неподходящ“" за провеждането на определен тип лечение. 
ни клетки (hiPS), трансформирани в подоцити с подлежаща базална мембрана, като са били свързани с капилярни ендотелни клетки. В резултат е било възможно да се пресъздаде in vivo симулация на подоцитна увреда с последваща албуминурия (6).

Следващата голяма стъпка ще бъде и пресъздаването на „човек-върху-чип“. Концепцията няма за цел да „отглежда“ хора в лаборатории, а отново да демонстрира най-малките функционални единици в тялото и да ги обедини в една цялостна и динамична система Фиг. 2 (7).

В заключение може да се каже, че развитието на биофизиологичните системи ще осигурят едно много по-точно и задълбочено опознаване на човешката физиология и патофизиология in vivo. Развитието на „органите-върху-чип“ ще доведе до изграждането на модели на болестите и ще улесни прилагането на нови терапевтични стратегии - „клинични проучвания-върху-чип".

\section{ЛИТЕРАТУРА}

1. Catherine K. Yeung and Jonathan Himmelfarb Kidneys on Chips Emerging Technology for Preclinical Drug Development Clin J Am Soc Nephrol 14: 144-146, 2019.

2. Olivier T. Guen and Berthiaume F. Incorporating mechanical strain in organs-on-a-chip: Lung and skin Biomicrofluidics. $2018 \mathrm{Jul}$; 12(4): 042207

3. Low LA and Tagle DA Microphysiological Systems ("Organs-on-Chips") for Drug Efficacy and Toxicity Testing Clin Transl Sci (2017) 10, 237-239

4. Kim S. and Takayama S. Organ-on-a-chip and the kidney Kidney Res Clin Pract. 2015 Sep; 34(3): 165-169

5. Jang KJ, Mehr AP, Hamilton GA, McPartlin LA, Chung $S$, Suh $K Y$, Ingber DE. Human kidney proximal tubule-on-a-chip for drug transport and nephrotoxicity assessment. Integr Biol (Camb) 2013;5:1119-1129

6. Musah S., Mammoto A., Ferrante T.C., Jeanty S.S.F., Hirano-Kobayashi M., Mammoto T., Roberts K., Chung S., Novak R., Ingram M., et al. Mature Induced-Pluripotent-Stem-Cell-Derived Human Podocytes Reconstitute Kidney GlomerularCapillary-Wall Function on a Chip. Nat. Biomed. Eng. 2017;1:0069. doi: 10.1038/s41551-017-0069

7. Jansen, J. et al. Human proximal tubule epithelial cells cultured on hollow fibers: living membranes that actively transport organic cations. Sci. Rep. 5, 16702; doi: 10.1038/ srep16702 (2015)

8. King SM, Higgins JW, Nino CR, Smith TR, Paffenroth EH, Fairbairn CE, Docuyanan A, Shah VD, Chen AE, Presnell SC and Nguyen DG (2017) 3D Proximal Tubule Tissues Recapitulate Key Aspects of Renal
Physiology to Enable Nephrotoxicity Testing. Front. Physiol. 8:123. doi: 10.3389/fphys.2017.00123

9. Eduardo Sosa-Hernández J. et al. Organs-on-aChip Module: A Review from the Development and Applications Perspective Micromachines (Basel). 2018 Oct; 9(10): 536

10. Kodzius R. et al. Organ-on-Chip Technology: Current State and Future Developments Genes (Basel). 2017 Oct; 8(10): 266.

11. Lin DSY, Guo F, Zhang B. Modeling organ-specific vasculature with organ-on-a-chip devices. Nanotechnology. 2019 Jan 11;30(2):024002. doi: 10.1088/1361-6528/aae7de. Epub 2018 Nov 5.

12. Huh D., Matthews B.D., Mammoto A., MontoyaZavala M., Hsin H.Y., Ingber D.E. Reconstituting Organ-Level Lung Functions on a Chip. Science. 2010;328:1662-1668. doi: 10.1126/ science.1188302.

13. Bhatia SN, Ingber DE Microfluidic organs-on-chips. Nat Biotechnol 32: 760-772, 2014 